\title{
Editorial: Why a Theme Issue on Public Health Ethics?
}

\author{
Theodore H. Tulchinsky, MD, MPH, ${ }^{1}$ \\ Antoine Flahault, $\mathrm{MD}, \mathrm{PhD}^{2}$
}

\begin{abstract}
This issue of Public Health Reviews is dedicated to exploring the origins of the modern dialogue on public health ethics, which are based on historic religious and humanistic origins and long held medical and public health values. The concept of solidarity is fundamental to public health ethics as health is not only an individual phenomenon, it is also a societal issue, and those working in health must have ethical guidelines within the law and civil protections of the courts and public opinion. However, in the $20^{\text {th }}$ century, medical doctors provided leadership and participation in euthanasia and genocide, which peaked with the Holocaust during World War II. From these horrific events emerged the Nuremberg Doctors Trials (1946), the Universal Declaration of Human Rights (1948), the United Nations Convention on the Prevention and Punishment of the Crime of Genocide (1948), the World Medical Association Declaration of Helsinki - Ethical Principles for Medical Research Involving Human Subjects (1964 and subsequently revised many times) to protect against such abuses. But the horrors continue to occur well into the $21^{\text {st }}$ century with incitement and acts of genocide. Biomedical ethics of individual patient care and protection of human rights in research are vital outcomes of these international codes. Public health is responsible for population health, are its ethical base is not synonymous with individual bioethics. The ideas of societal solidarity, social inequalities, culture and physical environment all play a role in the epidemiology of health and disease. Such determinants are interdependent and influence, shape and control the health status of individuals and communities. In this issue of $P H R$ we explore both gross violations of human rights in public health experimentation and in genocide of the last century. We also address current dilemmas of community rights versus individual rights in current public health. Ethical issues in public health apply both when evidence-based interventions are implemented as well as when there is neglect or failure to implement current best practices. The study and conversation of public health ethics are essential components of education of health professionals and the practice of public health.
\end{abstract}

\footnotetext{
${ }^{1}$ Deputy Editor, Public Health Reviews; Emeritus Professor, Braun School of Public Health, Hebrew University-Hadassah, Hadassah, Ein Karem, Jerusalem, Israel.

${ }^{2}$ Editor in Chief, Public Health Reviews; Professor of Medicine, Centre Virchow Villermé, Descartes School of Medicine, Sorbonne, Cité, Paris, France.
} 
Key Words: Public health ethics, human rights, community health rights, solidarity, case studies health ethics, Eugenics, Genocide

Recommended Citation: Tulchinsky TH, Flahault A. Editorial: why a theme issue on public health ethics? Public Health Reviews. 2012;34:7-17.

\section{THE ORIGINS OF ETHICAL VALUE SYSTEMS}

Living in a secular age, we sometimes forget the roots of the loftiest ideals of modern society. Ethics are based on value systems which have both religious and non religious origins. Religions, the philosophy of secular humanism, and the basic ideals of the field of medicine all place protection of human life as the highest moral value.

Religions from ancient times taught the Sanctity of Human Life, developed early in the Ten Commandments and the Biblical Pikuach Nefesh. These and later religious precepts of the three Abrahamic religions (Judaism, Christianity and Islam) and the Eastern traditions provided a basis for religious values around the world that relate to the intrinsic value of human life on earth and the obligation to protect it.

Since the $18^{\text {th }}$ century, secular humanism embraced the intrinsic worth and dignity of life as a human right, which are now codified in many fundamental documents of contemporary value systems. Religion and humanism place emphasis on the innate importance and role of human beings, individually, and collectively. Humanism justifies this by esteeming individual thought and values - over established doctrine or faith in a belief system - that center on humans, their capacities, and their inherent worth.

Medicine recognizes that the concept of concern, caring and respect for the value of human life and concern with dignity and respect as paramount values in care of the sick. Medical ethics has traditionally been based on precepts of the Hippocratic Oath of "do no harm", and the preservation of the dignity and privacy of patients. These traditional fundamental principles of medical ethics include: primacy of patient welfare and serving the interests of the patient; patient autonomy with empowerment to make informed decisions; and promotion of social justice within the health system without discrimination based on race, gender, socioeconomic status, religion or any other social category. ${ }^{1}$

The basic issues of values and ethics of public health are also vital to the continuing conversation of public health and in the education of current and future generations of public health professions. The Association of Schools of Public Health in the European Region (ASPHER) Values, Vision, Mission and Aims statement of 2007, republished as a preface to this Issue, sets the 
philosophical basis for ethical considerations in public health in the European context. ${ }^{2}$

We follow this with a number of editorials from prominent journals to show the range of views on the subject and its wide content discussing the contribution of ethics to public health globally under the auspices of the World Health Organization, ${ }^{3}$ in the United States, ${ }^{4}$ and a review by Lee on the theory of public health ethics. ${ }^{5}$ Dawson and Jennings address the fundamental issue of solidarity and its meaning for public health, on the proven premise that culture, environment and society within which we live influences, shapes and controls individual and community health determinants. The definition of solidarity arises from fundamental moral principles that are often challenged and need to be continuously addressed over time within the context of changing moral and political values, the law and its court interpretation. ${ }^{6}$

\section{ETHICAL FAILURES, HISTORICAL ABUSE, AND GENOCIDE}

Despite these value systems, medical ethics were, and are, frequently ignored or grossly abused. The foundation of modern medical ethics emerged from the abominable transgressions of the $20^{\text {th }}$ century, when genocide and mass murders were conducted in the name of distorted versions of public health. Modern concern with medical ethics was in large part derived from the Nuremberg Doctors' Trials following the role played by medical practitioners in the practice of eugenics-based on Social Darwinism-with mass murders, exterminations and Holocaust conducted by Nazi Germany during World War II. ${ }^{7}$ These issues are addressed in a moving preface by $\mathrm{McKee}^{8}$ of a powerful article by Lindert et al. on the participation of psychiatric professionals in the infamous Nazi "euthanasia" program in which medical doctors conceived, promoted, planned and implemented genocidal mass murder. ${ }^{9}$

The eminent public health author John M. Last defined genocide in his 2007 classic A Dictionary of Public Health as:

"the extermination, usually by brutal armed aggression, of members of an ethnic group. Human history offers many examples: massacres of Armenians by Turks in 1915, Stalin's collective farm policies in the Ukraine in the early 1930s, the Nazi extermination of Jews and Gypsies in ... 1938-1944; and in more recent history, the Ethnic Cleansing policies of the Serbs in the former Yugoslavia in 19921994, the massacre of the Tutsis by the Hutus in Rwanda in 1994, and the destruction of rural subsistence farming communities in Darfur, western Sudan, by government-supported tribesmen since 2004."10 
Why are the genocides of the $20^{\text {th }}$ century so relevant to ethics in public health today? For one thing they mostly originated from widespread public health and psychiatric eugenics movements based on theories of racial improvement that led to mass sterilization and later murder of innocent mentally ill or handicapped persons. American, Swedish and other national mental health psychiatry providers practiced lobotomies and other untested surgeries including crude shock and insulin therapies, forced commitment to mental hospitals, and forced sterilizations for those deemed unfit to breed well into the 1960s. German physicians followed the example of these and other proponents of genetic selection with compulsory sterilization of the mentally impaired but took further radical and tragic steps by carrying out gassing and planned starvation under the slogans of "euthanasia" and "racial purification of lives not worth living" in the infamous T4 program administered from Adolf Hitler's headquarters at Tiergartenstrasse 4 (T4).

The distinguished British historian, Sir Richard J. Evans (Regius Professor of History at the University of Cambridge) in his classic The Third Reich at War wrote:

"At the heart of German history in the war years lies the mass murder of millions of Jews in what the Nazis called 'the final solution to the Jewish question in Europe'. This book provides a full narrative of the development and implementation of this policy of genocide, while also setting it in the broader context of Nazi racial policies toward the Slavs, and towards minorities such as Gypsies, homosexuals, petty criminals and 'asocials.."

Evans continues:

"For many years, and not merely since 1933, the medical profession, particularly in the field of psychiatry, had been convinced that it was legitimate to identify a minority of handicapped as 'a life unworthy of life', and that it was necessary to remove them from the chain of heredity if all the many measures to improve the German race under the Third Reich were not to be frustrated. Virtually the entire medical profession has been actively involved in the sterilization programme, and from here it was but a short step in the minds of man to involuntary euthanasia." 11

The euthanasia program served as the precedent and developed the methodologies for the industrialized mass murder then applied to Jews, Romani (Gypsies) and others in the Holocaust during World War II. Many in the German medical profession led, organized or implemented the organized murder of mentally and physically handicapped, with efficient use of starvation, humiliation, and pseudo-scientific experimentation. ${ }^{12}$ 
Some played leading roles in euthanasia and even in establishing and leading the extermination camp of Treblinka. ${ }^{13}$ German medical complicity with the Holocaust, even with belated apologies, has had long lasting negative effects in the field of public health in the German speaking countries. ${ }^{14,15}$

The participation and indeed leadership of the medical profession made clear the vital importance of addressing medical ethics anew, beyond the general humanism and the Hippocratic Oath. The Nuremberg Doctors' Trial in 1946 defined the rights of individuals to informed consent, freedom from risk of pain, suffering and harm, voluntary withdrawal from research and the definable scientific value of the work. ${ }^{16}$ In 1948, the United Nations promulgated the Universal Declaration of Human Rights ${ }^{17}$ and the UN Convention on the Prevention and Punishment of the Crime of Genocide ${ }^{18}$ in response to the atrocities committed during World War II-serving together to define an international Magna Carta of religious and humanist philosophy of the Rights of Man which have since been ratified in principle by the overwhelming majority of member states of the UN.

Genocide and incitement to genocide, with precursors and early warning signs are crimes against humanity, and are still in our midst in the $21^{\text {st }}$ century. Former UN Secretary-General Kofi Annan, who among others failed to respond to the Rwanda genocide, said on their $65^{\text {th }}$ anniversary that the Universal Declaration of Human Rights: "emerged from the ashes of the Holocaust." The Declaration was intended "to save succeeding generations from the scourge of war". The Secretary-General added that "the United Nations has a sacred responsibility to combat hatred and intolerance. A United Nations that fails to be at the forefront of the fight against antiSemitism and other forms of racism denies its history and undermines its future." ${ }^{19}$ Yet acts of genocide and its incitement continue (Bosnia, Kosovo, Rwanda, and Darfur, and now Syria and most dangerously Iran. ${ }^{20}$

\section{ETHICS OF INDIVIDUAL RIGHTS VERSUS COMMUNITY BENEFITS}

Many articles in this issue of Public Health Reviews explore the distinction between the public health focus on population and community and individual health care. There are often conflicts between personal rights and those of the society and public health, whose task is to promote population health. Sometimes individual rights conflict with community rights.

However, individual rights exist within the boundaries of the law, made by elected representatives of the people and where application of the law is 
subject to interpretation by the courts whose role it is to balance between individual human rights, and the rights of society. For example, it is against the law to drive at excessive speed or drive on the wrong side of the road or drive without a seat belt or to drive a motorcycle without a protective helmet in many countries, in order to reduce self endangerment and a serious threat to others. It is against the law to smoke in public places including restaurants and bars in many countries. Many countries mandate public health measures to protect against disease and injury: compulsory pasteurization of milk, chlorination of water supplies, fortification of basic foods to protect infants against iodine deficiency disorders or neural tube defects, and some countries mandate immunization for school entry.

In 2002, the American Public Health Association published A Code of Ethics for Public Health, which is worth quoting in its entirety (See Appendix 1). ${ }^{21}$ In 2004, a compendium of case studies was published by the US Association of Schools of Public Health (ASPH), ${ }^{22}$ which serves as an outline that reminds us of the broad sweep of public health practice and responsibilities, but deals inadequately with public health responsibility for protection of human rights. This issue of $P H R$ examines many of these principles as they interact with society to prevent disease and promote health; to foster healthy societies; and to reduce social and health inequities within countries, regions and globally. This includes the responsibility to advocate and promote health interventions that involve the whole or part of the population at greater risk, and thus involves ethical issues of balancing community rights and individual rights.

\section{SCIENCE: THE GOOD, THE BAD AND THE SAFEGUARDS}

As is PHR's practice, we include in this issue a preface by an outstanding leader in science, Dr. Anthony S. Fauci, Director of the National Institute of Allergy and Infectious Diseases (NIAID). Dr Fauci led in the struggle to find medical treatment for HIV/AIDS in the early years of the pandemic when the only vehicles for intervention available were improvised health promotion methods. He describes how negotiations with the US Food and Drug Administration and with "informed consent" of leaders of the gay community to allow "fast tracking" of clinical trials of antiretroviral drugs in the early period of emergency of the epidemic when researchers were desperately seeking effective treatment that could work to save thousands of lives. ${ }^{23}$

In this issue we include case studies as examples of conflict between individual and community rights, such as childhood immunizations, now challenged with a surprisingly strong resistance by many modern young 
parents despite the success of immunization, which has saved countless millions of lives globally (El-Amin et al.). ${ }^{24}$ Reverby discusses the infamous Tuskegee and Guatemala syphilis experiments which cast a pall over the US Public Health Service until the present time for experimentation on humans in the Tuskegee case without adequately informing participants of their disease status and denying them life saving treatment when it became available; and in the Guatemala case where researchers actually actively infected unknowing subjects. ${ }^{25}$ Carter et al. address issues of ethics in health promotion, ${ }^{26}$ Coughlin et al. consider scientific integrity in research in public health, ${ }^{27}$ Teutsch and Rechel explore ethics of resource allocation in times of economic austerity, ${ }^{28}$ Gray discusses issues of ethics of publication, ${ }^{29}$ Edwards et al. recount challenges of their experiences with ethical clearance in international health policy and social sciences research ${ }^{30}$ and Aceijas argues the ethics of substitution therapy in harm reduction for drug addiction. ${ }^{31}$ Legal and ethical issues of mandatory fluoridation are highlighted by Zusman with Israel as a case study. ${ }^{32}$ The alarming neglect and low level of teaching of public health ethics in bachelors and master degree programs curricula in public health in Europe is examined by Aceijas, Brall et al. ${ }^{33}$

\section{CONTINUING RELEVANCE OF ETHICS TODAY}

Recognition of the need to continue to address ethical issues in Public Health and Medicine is being addressed by several entities worldwide. The US Presidential Commission for the Study of Bioethical Issues established by President Barack Obama in 2009 is mandated to oversee ethical standards of care and research in the US, ${ }^{34}$ while reportedly coerced sterilization of women inmates is still practiced in California's prison system. ${ }^{35}$ The US Centers for Disease Control is in the process of development of new case studies in public health ethics. In Europe, ASPHER is developing curriculum material of case studies in public health ethics, and possibly a future issue of $P H R$ could be a suitable vehicle to bring this material to the attention of teachers and students around the world.

We stress the responsibility of the academic public health community to teach these lessons to new generations and remind older generations of the horrors and pitfalls of value systems that can lead to gross abuse of human rights. We live in a time when a trained psychiatrist led a nation in genocide in the Balkans in the 1990s and when a Syrian ophthalmologist is currently committing mass murder and killing of his own people in a blood bath including use of poison gas leading to the deaths of over many thousands of civilian men, women and children. We live in a time when threats and 
incitement to genocide, potentially with chemical, biological or nuclear terrorism or warfare are continuing in the $21^{\text {st }}$ century, and seemingly beyond the capacity of international society to respond effectively. Public health professionals and institutions need to be in the forefront of those who cry out against such travesties.

Acts of incitement and genocide should be reportable events just as are infectious diseases, domestic brutality and non-communicable diseases. The public health professions must be vigilant and oppose abuse of medical metaphors to dehumanize people or groups as an early warning sign to incitement to genocide. We should promote international surveillance and condemnation of use of hate language in state sponsored or funded media, textbooks, and places of worship. We must not remain passive bystanders, but instead must speak out publicly on genocidal threats.

We live in a time when enormous progress is being made in public health capabilities to prevent disease and promote health. The growing capacity to save lives and promote health often requires proactive measures, which can be seen as limiting individual free choice. The choice between "right" from "wrong" is not always easy, can be very emotional and often highly politicized. Ethical conversation is therefore vital in public health education, but is still uncommon in master of public health programs in Europe. ${ }^{33}$ The essential purpose of this issue of $P H R$ is to bring this fundamental topic to the attention of teachers, students and others in public health to add this subject to the curricula of public health education.Many of the ethical dilemmas we face are when to act and apply public health law and evidence based capacity to prevent diseases when our interventions affect whole populations-some of whom object to state interference in their water, food, childcare practices and privacy. Finding the right ways to balance these often conflicting considerations within an ethical framework is a prime issue for present and future generations of public health workers.

Religion, humanism and the intrinsic values of health professions are all part of teaching these values and ethics to each generation, lest we forget and stray into dangerous areas of practice with great destructive force. We must not become indifferent to incitement to genocide nor can we be oblivious to harm to individual rights as well responsibility to protect those of society, in errors of both commission and omission. Public health is not simply a technical field; we are health professionals committed to saving lives and promoting health. We need to be continuously aware of the basic values and ethics of what we do and we need to advocate to fulfill our mission even when that enters the field of political controversy-such as what should be done to stop a brutal dictator from inflicting gas warfare on his own citizensto give real meaning to the oft repeated words: "Never again". 


\section{Appendix 1}

\section{Principles of the Ethical Practice of Public Health}

1. Public health should address principally the fundamental causes of disease and requirements for health, aiming to prevent adverse health outcomes.

2. Public health should achieve community health in a way that respects the rights of individuals in the community.

3. Public health policies, programs, and priorities should be developed and evaluated through processes that ensure an opportunity for input from community members.

4. Public health should advocate for, or work for the empowerment of, disenfranchised community members, ensuring that the basic resources and conditions necessary for health are accessible to all people in the community.

5. Public health should seek the information needed to implement effective policies and programs that protect and promote health.

6. Public health institutions should provide communities with the information they have that is needed for decisions on policies or programs and should obtain the community's consent for their implementation.

7. Public health institutions should act in a timely manner on the information they have within the resources and the mandate given to them by the public.

8. Public health programs and policies should incorporate a variety of approaches that anticipate and respect diverse values, beliefs, and cultures in the community.

9. Public health programs and policies should be implemented in a manner that most enhances the physical and social environment.

10. Public health institutions should protect the confidentiality of information that can bring harm to an individual or community if made public. Exceptions must be justified on the basis of the high likelihood of significant harm to the individual or others.

11. Public health institutions should ensure the professional competence of their employees.

12. Public health institutions and their employees should engage in collaborations and affiliations in ways that build the public's trust and the institution's effectiveness.

Source: Principles of the Ethical Practice of Public Health, Version 2.2@ 2002 Public Health Leadership Society. Quoted in: Thomas J, Sage M, Dillenberg J, Guillory VJ. A Code of Ethics for public health. Am J Public Health. 2002;92:1057-9. ${ }^{21}$

\section{REFERENCES}

1. ABIM Foundation, American Board of Internal Medicine, ACP-ASIM Foundation, American College of Physicians-American Society of Internal Medicine, European Federation of Internal Medicine. Medical professionalism in the new millennium: a physician charter. Ann Intern Med. 2002;136:243-6. Available from URL: http://annals.org/article.aspx?articleid=474090 (Accessed 28 September 2013). 
2. Tulchinsky TH, Birt CA, Kalediene R, Meijer A. ASPHER's values, vision, mission and aims: a working paper. ASPHER: December 2007. Available from URL: http://www.publichealthreviews.eu/show/a/90 (Accessed 9 July 2013).

3. Coleman, CH, Bouësseau M-C, Reis A. The contribution of ethics to public health. Bull World Health Organ. 2008;86:578. Available from URL: http:// www.who.int/bulletin/volumes/86/8/08-055954/en/index.html (Accessed 7 August 2012).

4. Rothstein MA. The future of public health ethics. Am J Public Health. 2012;102:9. Available from URL: http://ajph.aphapublications.org/doi/full/ 10.2105/AJPH.2011.3003655 (Accessed 25 September 2012).

5. Lee LM. Public health ethics theory: review and path to convergence. J Law Med Ethics. 2012;85-98.

6 .Dawson A, Jennings B. The place of solidarity in public health ethics. Public Health Rev. 2012;34:65-79.

7 . Shuster E. Fifty years later: the significance of the Nuremberg Code. N Engl J Med. 1997;337:1436-40.

8. McKee M. A preface: how ethics failed: lessons for public health for all time Public Health Rev. 2012;34:93-5.

9 .Lindert J, Stein Y, Guggenheim H, Jaakkola JJK, Strous RD. How ethics failed - the role of psychiatrists and physicians in Nazi programs from exclusion to extermination, 1933-1945. Public Health Rev. 2012;34:96-121.

10 .Last JM. Dictionary of Public Health. New York (NY): Oxford University Press; 2007.

11 .Evans RJ. The Third Reich at War. New York (NY): Penguin Press; 2006.

12 .Haque OS, De Freitas J, Viani I, Niederschulte B, Bursztajn HJ. Why did so many German doctors join the Nazi Party early? Int J Law Psychiatry. 2012;35:473-9.

13 .Strous RD. Dr. Irmfried Eberl (1910-1948): mass murdering MD. Isr Med Assoc J. 2009;11:216-8.

14 .Kolb S, Weindling P, Roelke V, Seithe H. Apologising for Nazi medicine: a constructive starting point. Lancet. 2012;380:722-3.

15 . Noack H. Governance and capacity building in German and Austrian public health since the 1950s. Public Health Rev. 2011;33:264-76.

16. The Nuremberg Code. Trials of War Criminals before the Nuremberg Military Tribunals under Control Council Law No. 10. Nuremberg, October 1946April 1949. Washington (DC): U.S. G.P.O, 1949-1953. Available from URL: http://www.ushmm.org/research/doctors/Nuremberg_Code.htm (Accessed 11 September 2013).

17 .United Nations. The Universal Declaration of Human Rights. UN: Paris; 1948. Available from URL: http://www.un.org/en/documents/udhr/ (Accessed 19 July 2013).

18. United Nations. Convention on the Prevention and Punishment of the Crime of Genocide. UN: Paris; 9 December 1948. Available from URL: http://untreaty. un.org/cod/avl/ha/cppcg/cppcg.html (Accessed 9 September 2013).

19 .United Nations. Remembrance and beyond. Available from URL: http://www. un.org/cyberschoolbus/holocaust/index.asp (Accessed 9 September 2013). 
20 . Richter ED. Commentary. Genocide: can we predict, prevent, and protect? J Public Health Policy. 2008;29:265.

21 . Thomas J, Sage M, Dillenberg J, Guillory VJ. A Code of Ethics for public health. Am J Public Health. 2002;92:1057-9.

22 .Jennings B, Kahn J, Mastroianni A, Parker LS (editors). Ethics and Public Health: Model Curriculum. The Hastings Center: Pittsbugh (PA); 2003.

23. Fauci AS. Preface: Evolving ethical issues over the course of the AIDS pandemic. Public Health Rev. 2012;34:19-24.

24 .El-Amin AN, Parra MT, Kim-Farley R, Fielding JE. Ethical issues concerning vaccination requirements. Public Health Rev. 2012;34:207-26.

25. Reverby SM. Ethical failures and history lessons: the U.S. Public Health Service research studies in Tuskegee and Guatemala. Public Health Rev. 2012;34:189-206.

26. Carter SM, Cribb A, Allegrante JP. How to think about health promotion ethics. Public Health Rev. 2012;34:122-45.

27 . Coughlin SS, Barker A, Dawson A. Ethics and scientific integrity in public health, epidemiological and clinical research. Public Health Rev. 2012;34:8092.

28 . Teutsch S, Rechel B. Ethics of resource allocation and rationing medical care in a time of fiscal restraint - US and Europe. Public Health Rev. 2102;34:22736.

29. Gray S. The ethics of publication in public health. Public Health Rev. 2012;34: 174-88.

30 .Edwards N, Viehbeck S, Hämäläinen R-M, Rus D, Skovgaard T, van de Goor I, Valente A, Syed A, Aro AR. Challenges of ethical clearance in international health policy and social sciences research: experiences and recommendations from a multi-country research programme. Public Health Rev. 2012;34:15673.

31. Aceijas C. The ethics in substitution treatment and harm reduction. An analytical review. Public Health Rev. 2012;34:251-62.

32 .Zusman SP. Water Fluoridation in Israel: ethical and legal aspects. Public Health Rev. 2012;34:237-50.

33. Aceijas C, Brall C, Schröder-Bäck P, Otok R, Maeckelberghe E, Stjernberg L, Strech D, Tulchinsky TH. Teaching ethics in schools of public health in the European Region: findings from a screening survey. Public Health Rev. 2012;34:146-55.

34.US Presidential Commission on Bioethical Issues. Moral science: protecting participants in human subjects research. Washington (DC): US Presidential Commission for the Study of Bioethical Issues; December 2011. Available from URL: http://bioethics.gov/sites/default/files/Moral\%20Science\%20June \%202012.pdf www.bioethics.gov (Accessed 10 January 2013).

35 .Johnson CJ. Female inmates sterilized in California prisons without approval. Center for Investigative Reporting. 7 July 2013. Available from URL: http:// cironline.org/reports/female-inmates-sterilized-california-prisons-withoutapproval-4917 (Accessed 9 September 2013). 